\title{
KINERJA PERUSAHAAN: PENGARUH KARAKTERISTIK DEWAN DAN STRUKTUR KEPEMILIKAN
}

\author{
Anita* dan Nurkhalifa Fajriya* \\ *Program Studi Akuntansi, Fakultas Ekonomi \\ Universitas Internasional Batam \\ Email:anita.lec@uib.ac.id; evafajriya@gmail.com
}

\begin{abstract}
The purpose of this observation was to empirically examine the effect of board characteristics and ownership structure on company performance. This observation used independent variables namely ownership concentration, state ownership, institutional ownership, managerial ownership, the board size, independent director, independent audit committee, audit committee meeting, and financial expert with the dependent variable as company performance.

This observation used sample of 416 companies that are appropriate with the specified characteristics and are listed on the 2014-2018 Indonesia Stock Exchange. This observation analysis data used SPSS and Eviews version 10 programs.

From the results of observations produced, the concentration of ownership, independent director, and independent audit committees have significant impact on company performance. While other variables such as institutional ownership, state ownership, managerial ownership, board size, audit committee meetings, and financial expert do not have impact that can affect company performance.
\end{abstract}

Keywords: company performance, ownership structure, board characteristics.

\section{PENDAHULUAN}

Hasil dari kegiatan manajemen adalah kinerja perusahaan. Kinerja perusahaan berasal dari kata kinerja yaitu hasil yang dicapai dari seorang pegawai dalam bentuk kualitas maupun kuantitas yang bekerja sesuai dengan tugas yang diberikan dan dilakukan dengan tanggung jawab (Emi, Arifin, \& Mustafa, 2006). Kinerja perusahaan berperan penting untuk menambah nilai suatu perusahaan, dengan kinerja perusahaan yang bagus, maka bisa menambah keuntungan bagi perusahaan. Perusahaan dikatakan bagus apabila perusahaan tersebut bisa menghasilkan keuntungan dengan stabil ditiap tahunnya dan tidak terjadi konflik di dalam perusahaan tersebut. Hal itu berarti hubungan perusahaan dengan karyawannya terjalin dengan baik karena pihak internal seperti manajer maupun direksi lainnya mampu mengontrol perusahaan dengan baik sehingga bisa menambah nilai perusahaan dan bisa menarik investor untuk menanam saham di perusahaan mereka. Untuk menilai suatu kinerja perusahaan biasanya dilakukan pendekatan yang informasi keuangannya didapat dari laporan tahunan maupun laporan keuangan lainnya.

Suatu perusahaan dibangun atau dibuat karena ada tujuan khusus, salah satunya untuk mencapai keuntungan yang telah ditargetkan dan mendapatkan laba sebanyak-banyaknya. Agar tujuan perusahaan tersebut tercapai maka perlunya kinerja dari suatu perusahaan. Suatu perusahaan dikatakan baik apabila kinerja perusahaan tersebut bagus dalam mengelola perusahaannya. Jika kinerja perusahaan tersebut jelek dan kurang bagus, maka perusahaan kemungkinan tidak berjalan dengan baik atau bisa terjadinya kebangkrutan.

Contoh kasus kinerja perusahaan yang terdapat di Indonesia yaitu kasus Farmasi Sido Muncul Tbk dan PT. Industri Jamu. Perusahaan yang sudah ada sejak tahun 1970 ini mengalami penurunan 
penjualan produk ditahun 2017 dengan penurunan yang terjadi sebesar 6,8 persen menjadi $\mathrm{Rp} 1,2$ triliun dengan angka sebelumnya sebesar Rp 1,29 triliun dengan periode yang sama di tahun 2016. Direktur keuangan dari perusahaan tersebut yaitu Ibu Venancia Sri Indrijati memberikan keterangan bahwa menurunnya pendapatan perusahaan dikarenakan turunnya penjualan produk penambah stamina energi. Hal ini karena sudah tidak menjadi tren dalam penjualan minuman penambah stamina, dengan penurunan ditahun 2017 sebesar 27 persen yang mana produk andalan dari perusahaan tersebut ialah Kuku Bima. Untuk itu pihak perusahaan akan melakukan revisi terkait strategi baru untuk menaikkan kembali kinerja perusahaan terutama dibagian keuangan pendapatan perusahaan dengan cara membuat produk terbaru yakni obat herbal.

Ada beberapa hal yang bisa memengaruhi kinerja suatu perusahaan salah satunya yaitu struktur kepemilikan. Struktur kepemilikan bisa berupa investor individual, institusi swasta maupun pemerintah. Struktur kepemilikan merupakan hal penting dalam kinerja perusahaan, yaitu dalam membuat tujuan perusahaan (Wahyudi \& Prasetyaning, 2006). Struktur kepemilikan mempunyai keahlian dalam memengaruhi jalannya suatu perusahaan yang kedepannya bisa memberikan pengaruh kinerja suatu perusahaan (Aluchna \& Kaminski, 2017).

Tidak hanya struktur kepemilikan, akan tetapi kinerja perusahaan juga biasa berhubungan dengan karakteristik dewan. Karakteristik dewan terkait dengan struktur dewan yang mana dianggap sebagai suatu alat yang bagus untuk mengawasi para pemegang saham. Tugas dewan sangatlah penting sebagai pengawas manajemen agar sesuai dengan aturan standar yang berlaku dan juga mencegah terjadinya praktik curang dan menambah nilai perusahaan tersebut. Struktur dewan merupakan pencapaian yang berasal dari penyetaraan kepentingan dari stakeholder yang beda salah satunya pemilik. Bisa dibilang kalau pemilik yang beda akan memperlihatkan karakteristik yang beda juga dari segi sikap dan opsi bagi tata kelola perusahaan yang memengaruhi struktur (Munisi, Hermes, \& Randoy, 2014).

Kinerja perusahaan merupakan hal yang penting untuk menentukan bagus tidaknya suatu perusahaan serta bermanfaat untuk menambah nilai suatu perusahaan sehingga dapat menarik investor membuat peneliti berkeinginan untuk melakukan observasi lebih lanjut agar mengetahui faktor yang memengaruhi kinerja perusahaan. Di laporan penelitian ini penulis akan menyelidiki hubungan variabel independen dan dependen yang diambil dari penelitian sebelumnya yang dilakukan oleh Aluchna dan Kaminski (2017) serta Ayda, Siti, dan Hairul (2017).

\section{KAJIAN LITERATUR DAN PENGEMBANGAN HIPOTESIS Kinerja Perusahaan \\ Verboncu dan Purcaru (2009)} menghargai bahwa kinerja adalah sebuah hasil yang diperoleh dari ekonomi, pemasaran, serta manajemen yang memberi karakteristik daya saing, efisiensi, serta efektivitas terhadap organisasi, dan komponen struktural dan proseduralnya. Sedangkan Bartoli (2015) percaya bahwa definisi kinerja harus dicapai melalui halhal seperti uji coba, evaluasi, efisiensi, efektivitas, dan kualitas.

Rivai dan Basri (2004) mendefinisikan kinerja perusahaan sebagai hasil kerja yang mampu diraih oleh satu orang maupun kelompok di suatu entitas sesuai dengan tugas dan tanggung jawab yang diberikan dalam upaya untuk tercapainya tujuan perusahaan secara sah sesuai dengan moral dan etika yang berlaku. Bisa dijelaskan jika perorangan maupun kelompok disuatu entitas tersebut menjalankan tugas mereka dengan bagus dan terarah baik maka mampu menghasilkan suatu kinerja perusahaan yang bagus pula nantinya.

Biasanya variabel yang dipakai perusahaan untuk menghitung kinerja 
perusahaan mereka yaitu menggunakan Return on Equity (ROE), Return on Asset (ROA) dan Economic Value Added (EVA) (Yasser \& Mamun, 2015). Namun pada observasi ini alat ukur yang digunakan adalah ROA. ROA ialah alat untuk mengukur efektivitas manajemen dalam pengelolaan investasinya yang digunakan perusahaan sebagai cara untuk menarik investor agar dapat menanamkan modal mereka (Santoso, 2013). Rumus yang biasa digunakan yakni ROA = laba bersih / total aset.

Di dalam kinerja perusahaan ada beberapa faktor yang bisa memengaruhi kinerja tersebut diantaranya struktur kepemilikan. Struktur kepemilikan perusahaan adalah hasil endogen dari seleksi kompetitif di mana berbagai keuntungan dan kerugian biaya diseimbangkan untuk sampai pada organisasi keseimbangan perusahaan (Ongore \& K'Obonyo, 2011). Struktur kepemilikan disebut sebagai elemen yang penting sebab mampu memutuskan masalah agensi di suatu perusahaan. Di lain sisi, pemilik dari perusahaan berkeinginan untuk memastikan kalau manajer mampu mengoperasikan perusahaan sesuai dengan keinginannya, sehingga kepentingan pemilik bisa dilindungi. Di lain sisi, manajer perusahaan biasanya lebih mendahulukan kepentingan individu sehingga dapat berdampak untuk kinerja perusahaan (Lestari, 2017).

Selain itu faktor yang lain bisa berpengaruh untuk suatu kinerja perusahaan ialah karakteristik dewan. Karakteristik dewan menjelaskan tentang proporsi atau struktur dari dewan yang terdiri atas dewan komisaris dan dewan direksi perusahaan yang mana mempunyai pengaruh untuk kinerja perusahaan, terkhusus perusahaanperusahaan publik dengan potensi masalah keagenan (agency problem) karena terpisahnya antara kepemilikan dan kontrol perusahaan. Karena mereka beranggapan kalau dewan yang banyak cenderung memiliki lebih banyak pengetahuan dan keterampilan yang mereka miliki dan perspektif yang mereka kumpulkan cenderung meningkatkan konflik kognitif. Selain itu karena adanya direktur independen mampu membawa informasi yang lebih baik untuk ukuran dewan dalam mengambil keputusan (Fauzi \& Locke, 2012).

\section{Konsentrasi Kepemilikan dan Kinerja Perusahaan}

Konsentrasi

kepemilikan merupakan keadaan yang sebagian besar sahamnya dikuasai oleh sebagian kecil baik individu maupun kelompok. Sehingga, individu maupun kelompok tersebut mempunyai saham yang relatif dominan dibanding pemegang saham yang lain. Konsentrasi kepemilikan di observasi ini diproksi dengan jumlah kepemilikan terbesar oleh individu. Dalam observasi yang dikerjakan oleh Altaf dan Shah (2018) mengungkapkan kalau adanya dampak yang timbul bagi konsentrasi kepemilikan untuk kinerja perusahaan. Sesuai observasi Jiang, Habib, dan Smallman (2009) yang mana pada penelitian tersebut memberikan pernyataan kalau semakin tingginya konsentrasi kepemilikan maka akan menimbulkan pengaruh yang bagus untuk kinerja perusahaan karena konsentrasi kepemilikan dianggap penting untuk menambah kemampuan dari pemegang saham untuk mengawasi manajemen. Dalam pengawasan tersebut dilakukan untuk mengatasi manajemen agar tidak salah dalam mengambil keputusan sehingga bisa meningkatkan kinerja perusahaan tersebut.

\section{H1: Konsentrasi kepemilikan berpengaruh signifikan positif bagi kinerja perusahaan.}

\section{Kepemilikan Negara dan Kinerja Perusahaan}

Thomsen dan Pedersen (2000)

dalam Aluchna dan Kaminski (2017) mengungkapkan bahwa sebagai kepemilikan negara internalizes hubungan antara pemerintah dan perusahaan memiliki efek negatif pada kinerja perusahaan. 
Karena tujuan politik dan sosial serta perilaku nirlaba dengan memaksimalkan perusahaan pemerintah yang dikendalikan menjadikan lingkungan organisatoris kaku. Studi ini juga selaras dengan studi Mao (2015) dan Ali, Qiang, dan Ashraf (2018) yang mana pada studi ini mengungkapkan kalau perusahaan dengan kepemilikan institusional dan negara yang sangat rendah mungkin sangat disukai.

\section{H2: Kepemilikan negara berpengaruh signifikan negatif bagi kinerja perusahaan.}

\section{Kepemilikan Institusional dan Kinerja Perusahaan}

Kepemilikan institusional mempunyai posisi yang berguna untuk meminimalisir konflik keagenan antara pemegang saham dengan manajer. Ketika kepemilikan institusi meningkat, mereka menjadi lebih aktif terlibat dalam tata kelola kepemilikan perusahaan mereka. Penekanan utama dari pemegang saham aktivis berevolusi menjadi fokus ke perusahaan yang berkinerja buruk dan menekan manajemen perusahaan tersebut untuk meningkatkan kinerja guna meningkatkan nilai pemegang saham. AlNajjar (2015) melakukan penelitian yang di mana temuan menunjukkan bahwa investor institusi baik domestik maupun asing dapat memantau tindakan dan keputusan manajemen secara efektif dan membantu untuk meningkatkan kinerja perusahaan. Karena kepemilikan saham besar mereka akan memiliki insentif yang lebih besar untuk memantau tata kelola perusahaan untuk memperoleh manfaat. Hal ini juga menemukan hubungan kepemilikan institusional dan kinerja perusahaan menjadi endogen.

\section{H3: Kepemilikan institusional berpengaruh signifikan positif bagi kinerja perusahaan.}

\section{Kepemilikan Manajerial dan Kinerja Perusahaan}

Ruan, Tian, dan Shiguang (2011)

dan Kamardin (2016) meneliti tentang dampak kepemilikan manajerial dengan kinerja perusahaan melalui struktur modal. Studi ini menemukan kalau kepemilikan manjerial berhubungan positif yang signifikan bagi kinerja perusahaan. Salah satu dari studi yang dilakukan oleh dua peneliti tersebut salah satunya mengungkapkan bahwa kepemilikan manajerial secara relevan berdampak bagi struktur modal dan struktur modal berdampak bagi kinerja perusahaan karena dengan kepemilikan manajer yang tinggi akan memudahkan manajer dalam pengambilan keputusan. Selain itu, struktur modal ditentukan secara endogen oleh nilai perusahaan dan kepemilikan manajerial di perusahaan publik yang dikelola sipil Tiongkok antara tahun 2002 dan 2007.

\section{H4: Kepemilikan manajerial berpengaruh signifikan positif bagi kinerja perusahaan.}

\section{Ukuran Dewan dan Kinerja Perusahaan}

Mohan dan Chandramohan (2018) mengungkapkan hasil penelitian mereka yang menunjukkan bahwa ada kebutuhan untuk melakukan proses pemantauan pada kinerja perusahaan yang unggul. Hasil yang didapat jika ukuran dewan meningkat melebihi titik tertentu maka akan membuat tingkat perusahaan menjadi rendah kinerjanya. Ini dikarenakan ukuran dewan yang banyak, tidak mampu menjadikan mekanisme tata kelola perusahaan menjadi lebih berkembang sehingga membuat nilai perusahaan menjadi rendah. Mayoritas studi telah mendokumentasikan relasi yang non signifikan diantara ukuran dewan terhadap kinerja perusahaan. Hubungan negatif juga terjadi di dalam studi Vo dan Phan (2013) dan Kao et al. (2018).

\section{H5: Ukuran dewan berpengaruh signifikan negatif bagi kinerja perusahaan.}

\section{Direktur Independen dan Kinerja Perusahaan \\ Direktur independen ialah orang yang bertugas dalam menjalankan operasional suatu perusahaan yang mana}


dalam tugasnya akan diawasi dan diberi masukan oleh komisaris independen. Mishra, Kumar, dan Kapil (2018) memperlihatkan kalau direktur independen berhubungan positif dan signifikan dengan kedua kinerja langkah-langkah, menambahkan kepercayaan pada teori "akses sumber daya". Direktur independensi sangat signifikan terkait dengan ukuran kinerja berbasis akuntansi. Ini mungkin karena dua hal. Pertama, faktor kontekstual manajemen promotor menciptakan situasi di mana direktur independen mungkin tidak memiliki suara independen dan kedua, meskipun direktur independensi memengaruhi kinerja perusahaan secara positif, pasar tidak memberikan banyak nilai padanya.

\section{H6: Direktur independen berpengaruh signifikan positif bagi kinerja perusahaan.}

\section{Komite Audit Independen dan Kinerja Perusahaan}

Independensi anggota komite audit diperlukan dalam mengawasi manajemen laba. Independen dari komite audit ini sendiri dapat bermanfaat dalam mengontrol laporan keuangan. Kallamu dan Saat (2015) melakukan penelitian tentang hubungan komite audit independen dengan kinerja perusahaan. Hasil didapat memperjelas kalau komposisi komite audit yang kebanyakan independen akan berdampak bagi kinerja suatu entitas. Observasi dari Naimah dan Hamidah (2017) juga menyatakan kalau keberadaan independensi komite audit mampu memberikan informasi akuntansi yang handal, sehingga independensi dari anggota komite audit diharapkan mampu menambah nilai suatu perusahaan.

\section{H7: Komite audit independen berpengaruh signifikan positif bagi kinerja perusahaan.}

\section{Rapat Komite Audit dan Kinerja Perusahaan}

Komite audit telah banyak dipelajari dari berbagai aspek yang beberapa diantaranya mengungkapkan kalau kehadiran komite audit mampu menaikkan kinerja atau mengurangi manajemen laba dan penipuan (Weir et al., 2002 dalam Ayda et al., 2017). Bouaziz dan Triki (2016) mengungkapkan jika frekuensi pertemuan yang dilakukan anggota komite audit ditiap tahunnya akan meningkatkan nilai perusahaan tersebut. Selain itu, Naimah dan Hamidah (2017) juga membuat penyataan dari hasil observasi yang dia lakukan yaitu sebagai pengawas proses akuntansi keuangan, melakukan pertemuan setidaknya empat kali setahun untuk menjamin kualitas pelaporan keuangan. Jika ukuran komite audit dan audit frekuensi rapat komite dapat meningkatkan proses akuntansi keuangan, sehingga diharapkan ukuran komite audit dan frekuensi pertemuan dapat meningkatkan kinerja perusahaan.

H8: Rapat komite audit berpengaruh signifikan positif bagi kinerja perusahaan.

\section{Financial Expert dan Kinerja Perusahaan}

Keahlian bidang keuangan di dalam anggota komite audit sepatutnya mempunyai wawasan yang baik untuk mengawasi dalam pelaporan keuangan disebut dengan financial expert. Adiati (2017) melakukan observasi tentang dampak keahlian keuangan dengan kinerja perusahaan. Hasil observasi tersebut menunjukkan dampak yang positif dari variabel tersebut di mana makin besar tingkat ahli keuangan komite audit, artinya semakin bagus juga kinerja suatu perusahaan tersebut karena semakin banyaknya anggota komite audit yang memiliki kualifikasi di bidang keuangan maka mereka mampu mengawasi laporan keuangan dengan baik. Ini selaras dengan observasi yang diteliti Azmi dan Rozainun (2012) yang mengungkapkan kalau adanya dampak yang positif diantara variabel saat komite audit yang anggotanya mempunyai kemampuan di bagian akuntansi maupun keuangan. 


\section{H9: Financial expert berpengaruh signifikan positif bagi kinerja perusahaan.}

\section{METODE PENELITIAN}

Sasaran observasi ini menggunakan entitas yang sudah tercatat di Bursa Efek Indonesia (BEI) pada tahun 2014-2018. Adapun target observasi ini memakai data sekunder yang berupa laporan tahunan entitas yang tercatat di BEI.Sampel dipilih dengan metode purposive sampling dengan tolak ukur sebagai berikut: (1) institusi yang sudah terdaftar di BEI sebelum tahun 2014; (2) tiap institusi memiliki laporan keuangan maupun laporan tahunan dari 2014 hingga 2018; (3) ditunjukkan secara umum laporan tahunannya per 31 Desember yang sudah diaudit; (4) menampilkan nominal dengan mata uang rupiah di laporan keuangannya.

\section{Variabel Dependen}

Variabel dependen yang terlibat pada observasi yang dilakukan ialah kinerja perusahaan. Di observasi ini, variabel dependennya diukur dengan satu aspek, yaitu ROA. ROA adalah ukuran yang lebih baik dari kinerja akuntansi, terutama untuk ekonomi yang baru muncul dan pasca transisi (Moscu et al., 2015; Berglof \& Claessens, 2006 dalam Aluchna \& Kaminski, 2017).

$\mathrm{ROA}=\frac{\text { laba bersih }}{\text { total aset }}$

\section{Variabel Independen}

\section{Konsentrasi Kepemilikan}

Konsentrasi kepemilikan

didefinisikan sebagai distribusi hak kepemilikan antara pihak-pihak yang berbeda yang secara kolektif memiliki perusahaan. Rendahnya tingkat jumlah pemegang saham akan menyebabkan konsentrasi kepemilikan tinggi (Aluchna \& Kaminski, 2017).

Konsentrasi kepemilikan $=\frac{\text { kepemilikan saham di atas 5\% }}{\text { jumlah saham beredar }} \times 100 \%$

\section{Kepemilikan Negara}

Kepemilikan

menggambarkan taruhan yang diselenggarakan oleh pemerintah atau lembaga yang berafiliasi pemerintah dan ditampilkan oleh karakteristik tertentu, posisi berpengaruh dan berdampak lebih perusahaan yang dikendalikan. Pemantauan oleh negara mampu menambah kinerja perusahaan sebab keterlibatan langsung serta resiko yang lebih rendah (Aluchna \& Kaminski, 2017).

Kepemilikan negara

$=\frac{\text { jumlah saham negara }}{\text { jumlah saham beredar }} \times 100 \%$

\section{Kepemilikan Institusional}

Kepemilikan institusional merupakan jumlah kepemilikan saham yang dimiliki suatu lembaga maupun institusi baik keuangan maupun non-keuangan (Alves, 2012). Kehadiran investor institusional dalam struktur kepemilikan dipandang sebagai bagian berarti dari tata kelola perusahaan (Aluchna \& Kaminski, 2017).

Kepemilikan institusional $=\frac{\text { jumlah saham institusi }}{\text { jumlah saham yang beredar }} \times 100 \%$

\section{Kepemilikan Manajerial}

Menurut konvergensi kepentingan tesis, kepemilikan manajerial menyesuaikan kepentingan manajer dengan orang-orang dari pemegang saham. Selain itu, kepemilikan manajerial dipandang sebagai mekanisme untuk mengurangi konflik prinsipal agen (Aluchna \& Kaminski, 2017).

Kepemilikan manajerial

$=\frac{\text { kepemilikan saham manajerial }}{\text { jumlah saham yang beredar }} \times 100 \%$

\section{Ukuran Dewan}

Jumlah anggota direksi dalam suatu institusi disebut ukuran dewan. Pengkaji menemukan kalau ukuran dewan yang normal lebih efisien dalam mengontrol perusahaan (Ayda et al., 2017). 
Ukuran dewan

= jumlah anggota dewan direksi di perusahaan

\section{Direktur Independen}

Direktur independen terhadap kinerja dan nilai perusahaan telah dipelajari oleh banyak peneliti. Studi penelitian semacam itu berusaha menyimpulkan opsi mana yang lebih baik, apakah memiliki direktur independen (orang luar), atau memiliki direktur internal, dengan mengevaluasi efek dari masing-masing alternatif komposisi dewan pada ukuran kinerja perusahaan (Ayda et al., 2017).

Direktur independen

$=\frac{\text { jumlah direktur independen }}{\text { jumlah direktur di perusahaan }}$

\section{Komite Audit Independen}

Komite audit independen merupakan perbandingan antara jumlah komite audit independen dengan jumlah anggota komite audit di institusi. Komite audit dengan persyaratan anggota independen minimum digabungkan dengan kemungkinan penipuan yang lebih rendah (Ayda et al., 2017).

Komite audit independen $=\frac{\text { jumlah anggota komite audit independen }}{\text { jumlah anggota komite audit }}$

\section{Rapat Komite Audit}

Setiap rapat yang dilaksanakan anggota komite audit suatu perusahaan dalam periode tertentu disebut sebagai rapat komite audit. Komite audit harus memenuhi setidaknya empat kali per tahun (sekali seperempat) sesuai Pasal 9 di Mandatory Corporate Governance Code (MCGC) tahun 2009 (Ayda et al., 2017).

Rapat komite audit

$=$ pertemuan komite audit dalam setahun

\section{Financial Expert}

Di dalam perusahaan anggota dari audit komite seharusnya memiliki kemampuan dalam bidang finansial untuk mengawasi pelaporan keuangan. Tiap anggota yang mempuyai keahlian bidang keuangan bisa menaikkan mutu yang disediakan laporan keuangan (Ayda et al., 2017).

Financial expert

$=$ komite audit dengan pengalaman atau kualifikasi keuangan

\section{HASIL PENELITIAN}

Observasi ini penulis memakai sampel berupa perusahaan yang ada di Bursa Efek Indonesia (BEI). Sampel data tersebut diambil mulai tahun 2014 sampai 2018 yang mana saat periode tersebut total perusahaan yang tercatat sebanyak 625 perusahaan. Akan tetapi, tidak semua perusahaan dipakai karena ada beberapa perusahaan yang tidak memenuhi karakteristik dalam pengujian ini sehingga perusahaan yang bisa dijadikan tolak ukur dalam pengujian ini hanya 416 perusahaan.

Tabel 1

Sampel Penelitian Bursa Efek Indonesia

\begin{tabular}{|l|r|}
\hline \multicolumn{1}{|c|}{ Keterangan } & \multicolumn{1}{|c|}{ Jumlah } \\
\hline Institusi yang terdaftar di BEI & $\begin{array}{r}\text { 625 Perusahaan } \\
\text { (155) Perusahaan } \\
\text { Institusi yang tidak terdaftar di BEI sebelum 2014 }\end{array}$ \\
Institusi yang tidak memiliki laporan yang lengkap dan belum diaudit & 416 Perusahaan \\
\hline Institusi yang memenuhi kriteria & $2014-2018$ \\
\hline Tahun observasi & 2.080 Data \\
\hline Jumlah data observasi & 234 Data \\
\hline Data outlier & 1.846 Data \\
\hline Jumlah data yang dipakai dalam observasi & \\
\hline
\end{tabular}

Sumber: Data sekunder diolah (2020).

Tabel 2

Statistik Deskriptif Kuantitatif

\begin{tabular}{|l|c|l|l|l|l|}
\hline & N & Minimum & Maksimum & Rata-rata & St. Deviasi \\
\hline
\end{tabular}




\begin{tabular}{|l|c|c|c|c|c|}
\hline ROA & 2080 & $-7,01001$ & 9,16706 & 0,02857 & 0,28544 \\
\hline Konsentrasi kepemilikan & 2080 & 0,055 & 0,99770 & 0,71118 & 0,17992 \\
\hline Kepemilikan negara & 2080 & 0,00000 & 0,90025 & 0,03431 & 0,14423 \\
\hline Kepemilikan institusional & 2080 & 0,00000 & 0,99997 & 0,621548 & 0,26681 \\
\hline Kepemilikan manajerial & 2080 & 0,00000 & 0,89444 & 0,034630 & 0,11645 \\
\hline Ukuran dewan & 2080 & 2 & 16 & 4,90 & 2,093 \\
\hline Direktur independen & 2080 & 0,00 & 1,0 & 0,16338 & 0,14847 \\
\hline Komite audit independen & 2080 & 0,20 & 1,0 & 0,82324 & 0,28765 \\
\hline Rapat komite audit & 2080 & 1 & 96 & 7,18 & 7,524 \\
\hline Financial expert & 2080 & 1 & 7 & 2,78 & 0,773 \\
\hline
\end{tabular}

Sumber: Data sekunder diolah (2020).

\section{Statistik Deskriptif}

Tabel di atas memaparkan rata-rata dari variabel kinerja perusahaan yang di hitung menggunakan ROA lebih besar 1, yaitu $0,02857(2,86 \%)$. Bisa disimpulkan kalau kinerja perusahaan yang tercatat di BEI terbilang bagus. Ini berarti karena keefesiensi dan keefektifan dari pihak atasan maupun karyawan suatu perusahaan sehingga mampu meningkatkan kinerja perusahaan tersebut.

Jumlah nilai maksimum konsentrasi kepemilikan $0,99770 \quad(99,77 \%) \quad$ yang dipegang oleh PT. Bentoel International Investama Tbk. Dengan rata-rata dari variabel tersebut sebesar 0,71118 (71,12\%). Ini memperlihatkan kalau konsentrasi kepemilikan yang dimiliki oleh BEI tergolong cukup tinggi karena bisa dilihat dari jumlah persentase kepemilikan tiap perusahaan tinggi. Hadirnya kepemilikan terkonsentrasi bisa diartikan sebagai dua kemungkinan yakni penyalahgunaan kontrol yang dimiliki oleh mereka sebagai kepentingan pemilik mayoritas atau konsentrasi kepemilikan diartikan sebagai sinyal dari kualitas dari perusahaan.

Kepemilikan negara memiliki ratarata adalah $0,03431 \quad(3,43 \%)$. Ini memperlihatkan kalau kepemilikan negara masih sedikit terkait dalam perusahaan yang tercatat di BEI. Nilai maksimum dari variabel kepemilikan negara sebesar 90,03\% yang dipegang oleh perusahaan PT. Kimia Farma (Persero) Tbk.

Rata-rata nilai dari variabel kepemilikan institusional adalah 62,15\%. Bisa diartikan kalau minat institusi untuk memiliki saham atas perusahaan yang tercatat di BEI tergolong tinggi.
Kepemilikan institusional tertinggi diwakili oleh PT. Bentoel International Investama Tbk dengan kepemilikan institusionalnya sebesar $99,99 \%$.

Nilai rata-rata dari variabel kepemilikan manajerial adalah 3,46\% yang menunjukkan kalau tingkat kepemilikan saham perusahaan dengan pihak manajemen perusahaan masih rendah. Dengan angka minimumnya adalah $0,00000 \%$. Ini mengindikasi kalau adanya perusahaan yang sahamnya masih belum dimiliki oleh pihak manajemen perusahaan, salah satunya seperti PT. Himalaya Energi Perkasa Tbk, PT. Visi Telekomunikasi Infrastruktur Tbk, PT. Humpuss Intermoda Transportasi Tbk, PT. Inti Bangun Sejahtera Tbk, dan lainnya.

Nilai maksimum dari variabel ukuran dewan adalah 2. Ini dikarenakan kalau terdapat perusahaan yang masih mempunyai direktur berjumlah 2 orang dalam perusahaannya, diantaranya PT. SMR Utama Tbk, PT. Siwani Makmur Tbk, PT. Star Petrcohem Tbk, PT. Trada Alam Minera Tbk, PT. Wicaksana Overseas International Tbk, dan lainnya.

Nilai standar deviasi sebesar 0,14847 dengan rata-rata yang dihasilkan senilai 0,16338. Ini mengartikan kalau rendahnya jumlah anggota direktur independen dalam perusahaan yang mana ada perusahaan yang tidak mempunyai direktur independen sama sekali, seperti PT. Express Transindo Utama Tbk, PT. Tifa Finance Tbk, PT. Kedaung Indah Can, PT. Merck Tbk, PT. Tiphone Mobile Indonesia Tbk, dan PT. Trada Alam Minera Tbk.

Angka maksimum dari komite audit independen adalah 1,0. Hal ini 
menunjukkan kalau ada beberapa yang tiap perusahaannya semua anggota komite auditnya adalah independen, seperti PT. Medco Energi Internasional Tbk, PT. Sierad Produce Tbk, PT. Suryamas Dutamakmur Tbk, PT. Golden Eagle Energy Tbk, PT. Salim Ivomas Pratama Tbk, dan PT. Sona Topas Tourism Industry Tbk.

Nilai minimum dari variabel rapat komite audit adalah 1. Ini menandakan kalau perusahaan sudah memenuhi kriteria yang ditentukan yang mana perusahaan harus mengadakan pertemuan tiap anggota komite audit minimal sebanyak 1 kali selama 1 periode.

Nilai standar deviasi sebesar 0,773 dengan angka maksimumnya berjumlah 7 , yang tandanya terdapat perusahaan yang di mana anggota dari komite audit mempunyai kemampuan maupun gelar di bidang akuntansi sebanyak 7 orang. Seperti perusahaan PT. Bank JTrust Indonesia Tbk dan PT. Bank Tabungan Negara (Persero) Tbk.

\section{Regresi Panel}

Hasil Uji Chow

Tabel 3

Hasil Uji Chow

\begin{tabular}{|l|c|c|c|}
\hline \multicolumn{1}{|c|}{ Effects Test } & Statistic & d.f. & Prob. \\
\hline $\begin{array}{l}\text { Cross-section } \\
\text { Chi-square }\end{array}$ & 1553,918315 & 475 & 0,0000 \\
\hline
\end{tabular}

Sumber: Data sekunder diolah (2020).

Tabel 3 menampilkan hasil data yang menjelaskan kalau hasil uji Chow menunjukkan angka probabilitas pada Cross-section Chi-square $<0,05$ yaitu sebesar 0,0000. Ini mengindikasikan kalau Tabel 6

Hasil Uji $t$ - Fixed Effect Model

\begin{tabular}{|l|c|c|c|c|c|}
\hline & Coeffi-cient & Std. Error & t-Statistic & Prob & Kesimpualan \\
\hline C & $-0,139$ & 0,065 & $-2,117$ & 0,034 & \\
\hline Konsentrasi kepemilikan & 0,078 & 0,034 & 2,272 & 0,023 & Terbukti \\
\hline Kepemilikan negara & $-1,11$ & $1,809$. & $-0,061$ & 0,951 & Tidak Terbukti \\
\hline Kepemilikan institusional & $-0,038$ & 0,025 & $-1,501$ & 0,133 & Tidak Terbukti \\
\hline Kepemilikan manajerial & 0,037 & 0,059 & 0,621 & 0,534 & Tidak Terbukti \\
\hline Ukuran dewan & 0,001 & 0,003 & 0,475 & 0,634 & Tidak Terbukti \\
\hline Direktur independen & 0,056 & 0,026 & 2,182 & 0,029 & Terbukti \\
\hline Komite audit independen & 0,102 & 0,038 & 2,683 & 0,007 & Terbukti \\
\hline Rapat komite audit & 0,001 & 0,001 & 1,023 & 0,306 & Tidak Terbukti \\
\hline Financial expert & 0,011 & 0,006 & 1,765 & 0,077 & Tidak Terbukti \\
\hline
\end{tabular}

model regresi panel yang akurat untuk dipakai adalah FEM.

\section{Hasil Uji Hausman}

Tabel 4

Hasil Uji Hausman

\begin{tabular}{|l|c|c|c|}
\hline Test Summary & $\begin{array}{c}\text { Chi-Sq. } \\
\text { Statistic }\end{array}$ & $\begin{array}{c}\text { Chi-Sq. } \\
\text { d.f. }\end{array}$ & Prob. \\
\hline $\begin{array}{l}\text { Cross-section } \\
\text { random }\end{array}$ & 25,782061 & 9 & 0,0022 \\
\hline
\end{tabular}

Sumber: Data sekunder diolah (2020).

Hasil uji Hausman sesuai dengan

Tabel 4 memperlihatkan kalau nilai probabilitas pada Cross-section random $<0,05$, yaitu 0,0022. Bisa disimpulkan kalau model regresi panel yang paling akurat untuk dipakai adalah FEM.

\section{Hasil Uji Hipotesis \\ Hasil Uji F}

Tabel 5

Hasil Uji F- Fixed Effect Model

\begin{tabular}{|c|c|l|}
\hline Cross-section fixed & Sig & Kesimpulan \\
\hline Prob. (F-statistic) & 0,0000 & Signifikan \\
\hline
\end{tabular}

Sumber: Data sekunder diolah (2020).

Hasil uji $F$ pada Tabel 5 yang didapat dari prob. (F-statistic) memperlihatkan angka signifikansinya $<0,05$, yaitu 0,0000 . Ini mengindikasikan kalau variabel bebas yang terlibat dalam observasi ini berdampak signifikan terhadap kinerja perusahaan dengan tolak ukur ROA. Hasil tersebut mengartikan kalau model yang dipakai di observasi ini bisa digunakan untuk memperkirakan penyebab apa saja yang dapat berdampak bagi kinerja suatu perusahaan yang mana tolak ukur menggunakan ROA. 
Sumber: Data sekunder diolah (2020).

Variabel konsentrasi kepemilikan pada Tabel 6 menunjukkan skala koefisien regresi sebesar 0,078 dan skala probabilitasnya sebesar 0,023 . Skala probabilitas $<0,05$ yang dimiliki variabel konsentrasi kepemilikan mengartikan kalau variabel tersebut mempunyai pengaruh signifikan positif bagi kinerja perusahaan. Hasil ini didukung oleh observasi Altaf dan Shah (2018) yang mengungkapkan bahwa tingginya tingkat kepemilikan yang terkonsentrasi bisa berdampak positif terhadap kinerja perusahaan, ini disebabkan kepemilikan yang tinggi konsentrasinya mampu menghasilkan struktur yang baik dengan pemilik pengendali yang terlibat di kinerja perusahaan dengan meningkatkan kemampuan pemegang saham dalam pengawasan manajer. Hasil observasi menerima Hipotesis 1 (H1) karena hasil yang didapat selaras dengan observasi yang dilakukan Alimehmeti dan Paletta (2009) dan Jiang et al. (2009).

Kepemilikan negara yang ditunjukkan pada Tabel 6 mengindikasikan skala koefisien regresi sebesar -1,11 dan skala probabilitas sebesar 0,951. Skala probabilitasnya lebih tinggi dari 0,05 yang dihasilkan berdasarkan penelitian ini bisa diartikan bahwa variabel kepemilikan negara tidak signifikan terhadap kinerja perusahaan. Hipotesis $2(\mathrm{H} 2)$ ditolak dalam observasi ini. Karena kinerja dari Badan Usaha Milik Negara (BUMN) cukup kurang efisien dibanding dengan swasta. Hal ini dikarenakan lemahnya kemampuan dari manajer, lemahnya insentif terhadap karyawan dalam melakukan efisien dan perusahaan pemerintah lebih dijadikan alat untuk politik dari pada memaksimalkan profit. Sedangkan swasta mereka menghasilkan profit sebanyak-banyaknya merupakan tujuan mereka bagi perusahaan yang ingin dicapai ini selaras dengan observasi Perotti (2004).

Nilai koefisien dari variabel kepemilikan institusional yang ditunjukkan pada Tabel 6 sebesar -0,038 dan angka probabilitas sebesar 0,133 . Hasil penelitian memperlihatkan kalau skala signifikannya lebih tinggi dari 0,05 dan bisa diartikan kalau variabel kepemilikan institusional tidak signifikan terhadap kinerja perusahaan. Ini seuai dengan observasi yang dilakukan oleh Wiranata dan Nugrahanti (2013) yang mana kepemilikan institusional tidak memiliki pengaruh bagi kinerja keuangan perusahaan karena terdapat asimetri informasi antara pemegang saham dengan manajer. Informasi yang dijadikan dasar perusahaan dalam melaksanakan pengawasan tidak sebagus informasi yang dipunyai oleh manajemen, sehingga manajemen mampu melaksanakan pengoperasian perusahaan dengan bebas. Hal ini membuat kepemilikan institusional tidak memengaruhi kinerja perusahaan. Sebab kinerja perusahaan tidak lagi bergantung kepada seberapa baiknya pengawasan yang diberikan perusahaan tetapi telah dibawah kendali oleh manajemen. Maka seberapa banyak jumlah saham yang dimiliki oleh suatu institusi tidak bisa menjamin pengawasan kinerja manajer mampu berjalan dengan efektif. Ini sejalan dengan observasi Sianipar, Hapsari, dan Boediono (2018) dan Susanti dan Mildawanti (2014). Hipotesis 3 (H3) ditolak.

Variabel kepemilikan manajerial pada Tabel 6 menunjukkan skala koefisien sebesar 0,037 dan skala probabilitas sebesar 0,534 . Angka probabilitas lebih besar dari 0,05 yang dimiliki variabel kepemilikan manajerial menyimpulkan kalau kepemilikan dari manajer tidak signifikan bagi kinerja perusahaan. Christiawan dan Tarigan (2007) menjelaskan kepemilikan manajerial yang terlalu rendah sehingga manajer sebagai pemegang saham minoritas belum mampu untuk ikut partisipasi aktif dalam membuat sebuah keputusan diperusahaan, sehingga tidak bisa berpengaruh untuk nilai perusahaan. Ini sesuai dengan observasi yang dilakukan Rustendi dan Jimmi (2010), Wiranata dan Nugrahanti (2013) dan Permanasari (2010). Hipotesis 4 (H4) ditolak. 
Variabel ukuran dewan pada Tabel 6 menjelaskan angka koefisien sebesar 0,001 dan angka probabilitas 0,634. Dengan skala probabilitas yang melebihi 0,05 maka bisa diartikan kalau ukuran dewan berpengaruh tidak signifikan bagi kinerja perusahaan. Ini bisa disebabkan karena semakin banyaknya jumlah dari dewan komisaris akan membuat badan mengalami kendala atau kesulitan untuk menjalankan tugasnya. Salah satunya terkendalanya komunikasi dan koordinir kerja di tiap anggota dewan itu sendiri, kesulitan dalam mengawas dan mengontrol tindakan manajemen, serta kesulitan dalam mengambil keputusan yang memiliki tujuan untuk perusahaan (Hidayat, Rasuli, \& Azlina, 2015). Hasil ini selaras dengan observasi yang dilakukan Mardiyati dan Murdayanti (2017). Hipotesis 5 (H5) ditolak.

Skala dari koefisien regresi pada variabel direktur independen yang dipaparkan di Tabel 6 mendapatkan angka sebesar 0,056 dan probabilitas sebesar 0,029 . Hasil penelitian menunjukkan kalau nilai probabilitas dari variabel tersebut $<0,05$ dan membuktikan kalau direktur independen berpengaruh signifikan positif bagi kinerja perusahaan. Ini berarti besarnya jumlah direktur independen dari suatu perusahaan membuat direktur lebih baik dalam melakukan tugasnya yakni mengawasi manajemen dalam kegiatan operasional perusahaan. Hal ini membuat pengelolaan dalam perusahaan semakin baik dan mampu menambah kinerja perusahaan tersebut salah satunya dalam laporan keuangan yang mana semakin banyak direktur independen maka pengawasan akan menjadi jauh lebih baik sehingga terhindar dari bias informasi dalam pelaporan keuangan. Adanya direktur independen diharapkan bisa membantu agar bisa diterima oleh pasar investor, karena kepentingan investor akan lebih dilindungi (Darwis, 2009). Hipotesis 6 (H6) diterima dalam observasi ini.

Tabel 6 menunjukkan skala koefisien regresi variabel komite audit independen sebesar 0,102 dengan skala probabilitas sebesar 0,007. Skala probabilitas yang didapatkan di penelitian ini $<0,05$ sehingga dapat diinterpretasikan kalau independensi komite audit berpengaruh signifikan positif bagi kinerja perusahaan. Karena besarnya jumlah independen anggota komite audit, sehingga pengawasan terhadap laporan keuangan dan pelaksanaan pengendalian internal perusahaan cukup baik karena independensi dari komite audit bisa dianggap lebih mampu dalam mempertahankan integritas dari laporan keuangan perusahaan dan membuat kinerja perusahaan baik. Hasil dari observasi ini menerima Hipotesis 7 (H7).

Skala dari koefisien regresi pada variabel rapat komite audit yang dipaparkan di Tabel 6 sebesar 0,001 dengan skala probabilitas sebesar 0,306. Penelitian ini memperlihatkan kalau skala probabilitas yang dimiliki variabel rapat komite audit >0,05 maka bisa disimpulkan kalau variabel pertemuan dari anggota komite audit tidak signifikan bagi kinerja perusahaan. Banyak sedikitnya pertemuan yang diadakan oleh anggota komite audit tidak bisa membuat tugas komite audit tersebut baik karena saat melakukan pertemuan artinya harus menggabungkan beberapa pendapat maupun ide dari tiap anggota dan saat fase yang tinggi dalam suatu masalah maka masalah akan semakin rumit karena berbedanya pemikiran tiap anggota (Lary et al., 2011). Alasan lainnya bisa juga karena rapat yang sudah diselenggarakan tersebut kurang berjalan dengan efektif sehingga tidak membantu sama sekali bagi perusahaan. Hasil ini selaras dengan observasi yang dilakukan Muslih (2019). Hipotesis 8 (H8) ditolak.

Skala koefisien regresi yang dipaparkan pada Tabel 6 untuk variabel financial expert sebesar 0,011 dan nilai probabilitas sebesar 0,077. Variabel financial expert memiliki nilai probabilitas $>0,05$ sehingga bisa diartikan kalau financial expert tidak signifikan dengan kinerja perusahaan. Dikarenakan keahlian yang dimiliki komite audit lebih 
memengaruhi masalah pada manajemen laba ketimbang pada kinerja perusahaan. Sehingga ada atau tidaknya keberadaan keahlian dari anggota komite audit tidak membuat kinerja perusahaan baik dan mampu mengawasi pelaporan keuangan dengan baik. Ini selaras dengan observasi yang dilakukan Kallamu dan Saat (2015) dan Ayda et al. (2017). Hipotesis 9 (H9) ditolak.

\section{Hasil Uji Koefisien Determinasi}

\section{Tabel 7}

Hasil Uji Koefisien Determinasi

\begin{tabular}{|l|c|}
\hline Variabel Dependen & Adjusted $R$-Squared \\
\hline Kinerja perusahaan & 0,432333 \\
\hline
\end{tabular}

Sumber: Data sekunder diolah (2020).

Hasil yang disajikan pada Tabel 7 mengartikan kalau skala adjusted $R$ squared pada model regresi ini sebesar 0,432333 atau $43,23 \%$. Hal tersebut menandakan kalau 43,23\% variabel terikat yakni kinerja perusahaan dengan tolak ukur yang dipakai adalah ROA mampu diinterpretasi oleh variabel independennya. Sebesar 56,77\% variabel terikat yang diukur menggunakan ROA dijelaskan oleh faktor atau variabel lain yang tidak digunakan dalam pengujian ini.

\section{KESIMPULAN}

Observasi ini dilakukan guna mengetahui pengaruhnya dari struktur kepemilikan serta karakteristik dewan bagi kinerja perusahaan. Pada struktur kepemilikan terdapat konsentrasi kepemilikan, kepemilikan negara, kepemilikan institusional dan kepemilikan manajerial. Sementara karakteristik dewan terdapat ukuran dewan, direktur independen, komite audit independen, rapat komite audit, dan financial expert sebagai variabel independennya.

Observasi ini membuktikan kalau direktur independen, konsentrasi kepemilikan, dan komite audit independen berhubungan signifikan positif bagi kinerja perusahaan. Sedangkan kepemilikan manajerial, kepemilikan negara, kepemilikan institusional, ukuran dewan, financial expert, dan rapat komite audit tidak memiliki hubungan yang signifikan bagi kinerja perusahaan.

Dengan adanya konsentrasi kepemilikan yang rendah maka akan meningkatkan pengawasan yang dilakukan pemegang saham terhadap manajer dan adanya direktur independen serta komite audit independen yang jumlahnya besar maka akan mampu membantu sekali dalam pengawasan laporan keuangan agar tidak terjadi bias informasi pada pelaporan keuangan. Sehingga laporan keuangan tersebut bisa dipercaya penuh oleh para investor dan membuat nilai dari kinerja perusahaan meningkat.

Terdapat beberapa kekurangan di observasi ini, diantaranya: (1) Terbatasnya sampel entitas yang mana tidak semua entitas yang ada di Bursa Efek Indonesia (BEI) bisa digunakan untuk sampel. Ini dikarenakan tidak sesuai dengan tolak ukur data yang diperlukan dalam pengkajian ini; (2) Hasil dari koefisien determinasi adjusted $R$-squared adalah 43,23\%. Mengartikan kalau variabel independen bisa menjelaskan variabel kinerja perusahaan hanya sebesar 43,23\%. Ini termasuk nilai yang kecil karena tidak sampai setengahnya. Sedangkan 56,77\% sisanya dijelaskan oleh faktor lainnya.

Berdasarkan uraian keterbatasan di atas maka terdapat beberapa rekomendasi, antara lain: (1) Di penelitian selanjutnya disarankan peneliti harus menambah jumlah sampel penelitiannya. Seperti menambah jumlah tahun sampel yang digunakan; (2) Sebaiknya peneliti harus menambah lagi variabel independen yang bisa memengaruhi variabel dependen. Seperti kepemilikan keluarga (Astuti, Rahman, \& Sudarno, 2015) atau kepemilikan asing (Shubita \& Shubita, 2019) dan lainnya.

\section{DAFTAR PUSTAKA}

A Bartoli, B. C. (2015). Management dans les organizations publiques. In - 4ème édition (4ème éditi). Dunod, Paris.

Adiati, Y. (2017). Pengaruh karakteristik komite audit terhadap kinerja 
perusahaan perbankan di bursa efek indonesia tahun 2013 - 2015. Diponegoro Journal of Accounting, 6(4), $\quad 1-15$. https://doi.org/ISSN(Online): 23373806

AL-Najjar, D. (2015). The effect of institutional ownership on firm performance: Evidence from Jordanian listed firms. International Journal of Economics and Finance, 7(12), 97. https://doi.org/10.5539/ijef.v7n12p97

Ali, A., Qiang, F., \& Ashraf, S. (2018). Regional dynamics of ownership structure and their impact on firm performance and firm valuation: A case of Chinese listed companies. Review of International Business and Strategy, 28(1), 128-146. https://doi.org/10.1108/RIBS-022017-0017

Alimehmeti, G., \& Paletta, A. (2009). Ownership concentration and effects over firm performance: Evidences from Italy. European Scientific Journal, 8(22), 39-49.

Altaf, N., \& Shah, F. A. (2018). Ownership concentration and firm performance in Indian firms: does investor protection quality matter? Journal of Indian Business Research, 10(1), 33-52. https://doi.org/10.1108/JIBR-01-20170009

Aluchna, M., \& Kaminski, B. (2017). Ownership structure and company performance: a panel study from Poland. Baltic Journal of Management, 12(4), 485-502. https://doi.org/10.1108/BJM-01-20170025

Alves, S. (2012). Ownership structure and earnings management: Evidence from Portugal. Australian Accounting Business and Finance Journal, 6(1), 57-74.

https://doi.org/10.5539/ijbm.v7n15p88

Astuti, A. D., Rahman, A., \& Sudarno. (2015). Pengaruh kepemilikan keluarga terhadap kinerja perusahaan dengan agency cost sebagai moderating.

Ayda, F., Siti, N. O., \& Hairul, A. (2017). Corporate governance effect on firms ', performance - evidence from the UAE. https://doi.org/10.1108/JEAS-012016-0002

Azmi, H., \& Rozainun, A. (2012). Impact of the amendments of Malaysian code of corporate governance (2007) on governance of GLCs and performance. International Journal of Social, Behavioral, Educational, Economic, Business and Industrial Engineering, 6(11), 3181-3186.

Bouaziz, Z., \& Triki, M. (2016). The impact of the board of directors on the financial performance of Tunisian companies. Corporate Board: Role, Duties and Composition, 8(3), 6-21. https://doi.org/10.22495/cbv8i3art1

Christiawan, Y. J., \& Josua Tarigan. (2007). Kepemilikan manajerial: kebijakan hutang, kinerja dan nilai perusahaan. Jurnal Akuntansi Dan Keuangan, 9(1), $1-8$.

https://doi.org/10.9744/jak.9.1.pp.1-8

Darwis, H. (2009). Corporate governance terhadap kinerja perusahaan. Jurnal Keuangan Dan Perbankan, 13(3), 418430.

Emi, Arifin, U., \& Mustafa., R. L. O. (2006). Analisis kinerja karyawan dalam memberikan pelayanan kepada custumer pada perseroan terbatas (PT). Sinar Galesong Kendar. 158-165.

Fauzi, F., \& Locke, S. (2012). Board structure, ownership structure and firm performance : A study of New Zealand. (1976).

Hidayat, R., M. Rasuli, M., \& Azlina, N. (2015). Pengaruh good corporate governance dan ukuran perusahaan terhadap kinerja keuangan perusahaan (studi empiris pada perusahaan perbankan yang terdaftar di BEI 20102013). Jurnal Online Mahasiswa Fakultas Ekonomi Universitas Riau, 2(1), 1-12.

Jiang, H., Habib, A., \& Smallman, C. (2009). The effect of ownership 
concentration on CEO compensationfirm performance relationship in New Zealand. Pacific Accounting Review, 21(2), 104-131. https://doi.org/10.1108/011405809110 02053

Kallamu, B. S., \& Saat, N. A. M. (2015). Audit committee attributes and firm performance: Evidence from Malaysian finance companies. Asian Review of Accounting, 23(3), 206-231. https://doi.org/10.1108/ARA-11-20130076

Kamardin, H. (2016). Ethics, governance and corporate crime: Challenges and consequences.

39.

https://doi.org/10.1108/S2043-

052320140000006002

Kao, M., Hodgkinson, L., \& Jaafar, A. (2018). Ownership structure, board of directors and firm performance: evidence from Taiwan. https://doi.org/10.1108/CG-04-20180144

Lary, Akeel M, \& Taylor, D. W. (2011). Governance characteristics and role effectiveness of audit committees. Managerial Auditing Journal, 21(4), 336-354.

https://doi.org/10.1108/026869012112 17969

Lestari, N. P. (2017). Pengaruh dimensi struktur kepemilikan terhadap kinerja perusahaan manufaktur. 6(3), 742-751.

Mao, L. (2015). State ownership, institutional ownership and relationship with firm performance: Evidence from Chinese public listed firms.

Mardiyati, U., \& Murdayanti, Y. (2017). Pengaruh ukuran dewan, kepemilikan saham oleh direktur, dan jender terhadap kinerja keuangan perbankan. Jurnal Manajemen, 20(3), 402-415. https://doi.org/10.24912/jm.v20i3.15

Mishra, Rakesh Kumar, \& Kapil, S. (2018). Effect of board characteristics on firm value: evidence from India. South Asian Journal of Business Studies, 7(1), 41-72. https://doi.org/10.1108/sajbs-
08-2016-0073

Mohan, A., \& Chandramohan, S. (2018). Impact of corporate governance on firm performance : Empirical evidence from India. 6(2), 209-218.

Munisi, G., Hermes, N., \& Randøy, T. (2014). Corporate boards and ownership structure: Evidence from Sub-Saharan Africa. International Business Review, 23(4), 785-796. https://doi.org/10.1016/j.ibusrev.2013. 12.001

Muslih, M. (2019). Pengaruh organ komisaris terhadap kinerja BUMN perbankan yang terdaftar di bursa efek Indonesia yang masuk klasifikasi LQ 45. Forun Keuangan Dan Bisnis (FKBI), 7, 15-30.

Naimah, Z., \& Hamidah. (2017). The role of corporate governance in firm performance. SHS Web of Conferences, 34 , 13003. https://doi.org/10.1051/shsconf/20173 413003

Ongore, V. O., \& K'Obonyo, P. O. (2011). Effects of selected corporate governance characteristics on firm performance: Empirical evidence from Kenya. International Journal of Economics and Financial Issues, 1(3), 99-122.

Permanasari, W. I. (2010). Pengaruh kepemilikan manajemen, kepemilikan institusional, dan corporate social responsibility terhadap nilai perusahaan.

Perotti, E. C. (2004). State ownership: A residual role? (September), 1-25.

Ruan, W., Tian, G., \& Shiguang, M. (2011). Managerial ownership , capital structure and firm value: Evidence from China's civilian-run firms. Australasian Accounting Business and Finance Journal, 5(3), 73-92. https://doi.org/10.1016/j.ecolecon.201 7.05.004

Rustendi, T., \& Jimmi, F. (2010). Pengaruh hutang dan kepemilikan manajerial terhadap nilai perusahaan pada perusahaan manufaktur. Jurnal 
Akuntansi FE Unsil, 3(1), 411-422.

Santoso, Y. W. (2013). Analisis penghitungan roe, roa dan eva terhadap kinerja keuangan.

Shubita, R., \& Shubita, M. F. (2019). The impact of foreign ownership on corporate governance: Evidence from an emerging market. Investment Management and Financial Innovations, 16(2), 101-115. https://doi.org/10.21511/imfi.16(2).20 19.09

Sianipar, N. B., Hapsari, D. W., \& Boediono, E. (2018). Pengaruh kepemilikan instusional, kepemilikan manajerial , komisaris independen terhadap return on asset (ROA) (studi kasus pada perusahaan sektor perkebunan yang terdaftar di bursa efek Indonesia pada tahun $2011-2015$ ). EProceeding of Management, 5(1), 646653.

Susanti, T., \& Mildawanti R.M. (2014). Pengaruh kepemilikan manajemen, kepemilikan institusional dan corporate social responsibility terhadap nilai perusahaan. Jurnal Ilmu \& Riset Akuntansi.

Verboncu, I., \& Purcaru, I. (2009). A managerial modernization model in crisis conditions. Management Şi
Marketing (Bucureşti), 4(3), 65-76.

Vo, D., \& Phan, T. (2013). Corporate governance and firm performance: empirical evidence from vietnam duc vo. (April 2013).

Wahyudi, \& Prasetyaning, P. H. (2006). Implikasi struktur kepemilikan terhadap nilai perusahaan: Dengan keputusan keuangan sebagai variabel intervening. 23-26.

Wiranata, Y. A., \& Nugrahanti, Y. W. (2013). Pengaruh struktur kepemilikan terhadap profitabilitas perusahaan manufaktur di Indonesia. Jurnal Akuntansi Dan Keuangan, 15(1), 1526.

https://doi.org/10.9744/jak.15.1.15-26

Yasser, Q. R., \& Mamun, A. Al. (2015). Effects of ownership concentration on firm performance: Pakistani evidence. Journal of Asia Business Studies, 9(2), 162-176.

https://doi.org/10.1108/JABS-072014-0047

Zainal, V. R., Ramly, M., Mutis, T., \& Arafah, W. (2004). Manajemen sumber daya manusia untuk perusahaan (Pertama). Jakarta: PT. Raja GrafindoPersada. 